\title{
Swój „Obcy”. Wewnętrzni uchodźcy w Gruzji
}

\section{GeOgrafia KaUkAZU - POGRANICZE NA PERYFERIACH}

\section{W} Ś́wiadomości Europejczyków Kaukaz podzielony Jest na PóŁNocNy i Południowy. Kaukaz Południowy, jak zauważa Maciej Ząbek, kojarzony jest przede wszystkim z Gruzją, a Północny „w wyobraźni Europejczyka, w tym też Polaka, czasami w ogóle nie istnieje" (Ząbek, 2010, s. 18). Jednak w rzeczywistości Kaukaz podzielić jest bardzo trudno. To monolit. Planeta, jak trafnie określa go Wojciech Górecki, która „zamyka się między Morzem Czarnym na zachodzie a Morzem Kaspijskim na wschodzie oraz między równiną Donu na północy a Turcją i Iranem na południu. Mierzy czterysta czterdzieści tysięcy kilometrów kwadratowych. Tyle, co Szwecja. Niewiele" (Górecki, 2010, s. 11). Mieszkające tam narody bardzo wiele różni, ale jednocześnie bardzo wiele łączy, dlatego też ciężko jest dzielić Kaukaz na administracyjne kawałki. Mapa polityczna świata w jakimś sensie warunkuje podziały graniczne, państwowe, czasem kulturalne czy etnograficzne. Niemniej jednak Kaukaz to mozaika ludów i narodów, wierzeń i religii, kultur i cywilizacji a przede wszystkim języków. To pogranicze Europy i Azji, styk dwóch interiorów cywilizacyjnych. To tutaj kończy się Europa i zaczyna Azja, swoje granice zamyka chrześcijaństwo i rozpoczyna islam, i odwrotnie. Wszystko zależy od tego, z której strony mapy patrzymy. Jak zauważa Wojciech Jagielski w „Dobrym miejscu do umierania” „Kaukaz jest zaściankiem, końcem świata. Tu kończy się Europa i Azja, Wschód i Zachód, Północ i Południe. Dla Europy prawosławne Armenia i Gruzja są peryferiami chrześcijańskiego świata. Takimi samymi, jak Azerbejdżan i muzułmańskie kaukaskie republiki dla Azji $\mathrm{i}$ islamu. $\mathrm{W}$ dodatku jest to zaścianek odgrodzony od reszty świata dwoma morzami (...) i potężnymi łańcuchami górskimi (...). Kompleks zaścianka jest przyczyną powszechnej wśród kaukaskich narodów nieufności wobec obcych i przekonania o własnej absolutnej wyjątkowości (...). Odgradzając się od reszty świata - z przymusu, a nie z wyboru - sto kaukaskich narodów żyło przez wieki we własnym, zamkniętym środowisku, nie stykając się nawet z sąsiadami ani ich nie poznając. 
Utwierdzane przez wieki stereotypy powodowały ciasnotę poglądów, kategoryczność sądów i niecierpliwość wobec wszelkiej odmienności” (Jagielski, 2010, s. 10-11). Nie tylko jednak owy styk kultur i cywilizacji jest fascynujący. Kaukaz to pogranicze na peryferiach, funkcjonujące w naszej świadomości jako Wschód, Orient. Mateusz Gralewski w swoich wspomnieniach z niewoli na Kaukazie w czasach carskiej Rosji pisze, iż „obojętność Europejczyków na los ludów kaukaskich przypisać należy niezrozumieniu przez nich wagi posiadania Kaukazu" (Gralewski, 2015, s. 530). O te peryferia walczyły ze sobą wielkie mocarstwa: Persja, Turcja i wreszcie Rosja, ale Kaukaz to nie Rosja, mimo, że znaczna jego część znajduje się w jej granicach administracyjnych. „Postrzeganie Kaukazu jako peryferii z perspektywy Brukseli i Waszyngtonu, tak samo zresztą, jak Moskwy, Stambułu czy Teheranu, jest uwarunkowane oczywiście słabością polityczną i gospodarczą. Uzależnieniem od tych centrów, położonych w dodatku w znacznym od niego oddaleniu, i ścieraniem się w tym rejonie wpływów, co jest jedną z bardziej charakterystycznych cech obszarów peryferyjnych" (Ząbek, 2010, s. 21). Na wyjątkowość tego terenu wpływ ma także jego ukształtowanie. Góry stanowią naturalną barierę izolacyjną, pomagają w tworzeniu się konserwatywnych społeczności, żyjących według własnych praw i zwyczajów. To naturalne odgrodzenie od świata zewnętrznego prowadzi do „miniaturyzacji systemów społeczno-gospodarczych” (Ząbek, 2010, s. 21) i poczucia wyjątkowości własnej grupy, klanu czy wreszcie narodu.

\section{METODOLOGIA I CHARAKTER PRZEPROWADZONYCH BADAŃ}

NINIEJSZA PRACA JEST WYNIKIEM KILKUNASTU PODRÓŻY NA KAUKAZ ORAZ cZterdziestu czterech rozmów przeprowadzonych z wewnętrznymi uchodźcami z Abchazji. Celem pracy było udzielenie odpowiedzi na pytanie, czy wewnętrzni uchodźcy (Gruzini) są traktowani na równi z obywatelami Gruzji, nie podlegają społecznej izolacji, wykluczeniu i stygmatyzacji, oraz sprawdzenie warunków w jakich żyją dwadzieścia dwa lata po wojnie.

Rozmowy zostały przeprowadzone w dwóch gruzińskich miastach - Tbilisi oraz graniczącym z Abchazją Zugdidi i stanowią one materiał źródłowy niniejszej pracy. Badania miały charakter terenowy i zostały przeprowadzone w roku 2015. Spotkania z uchodźcami odbywały się w ośrodkach dla uchodźców, w nowopowstałym, specjalnie dla nich zaprojektowanym osiedlu mieszkaniowym w Zugdidi oraz w prywatnych mieszkaniach i domach. Trzy rozmowy przeprowadzone były 
na bazarze w Zugdidi, siedem w restauracjach. Wybór miejsca zależał od decyzji rozmówcy. Rozmowy przeprowadzono w języku rosyjskim. Największym problemem było zdobycie zaufania rozmówców. Niekiedy wymagało to kilku spotkań. W celu unikania powtarzania informacji zastosowana została technika swobodnej rozmowy. Większość rozmówców chętnie godziła się na rozmowę, zapraszała do mieszkań i pozwalała na fotografowanie wnętrz. Mieszkańcy obozów dla uchodźców cieszyli się, że ktoś z zagranicy interesuje się ich losem. Badania zostały przeprowadzone samodzielnie. Do rozmówców trafiałam przez prywatne znajomości oraz polecanie dalej metodą tzw. „łańcuszka”. Celem badań było przekonanie się na własne oczy, co dzieje się z gruzińskimi uchodźcami po wojnie, która zakończyła się dwadzieścia dwa lata temu. Zdobycie informacji, w jakich warunkach mieszkają, poprzez samodzielny i obiektywny ogląd sytuacji.

\section{ŹróDŁA KONFLIKTÓW NA KaUKAZIE. ZaRZEWIE WOJNY GRUZIŃSKO-ABCHASKIEJ}

KAUKAZ JEST JEDNYM Z NAJBARDZIEJ NIESPOKOJNYCH I NIESTABILNYCH kawałków świata. Po upadku ZSRR jeden konflikt ciągnął za sobą następny, tak jakby jeden stawał się przedłużeniem poprzedniego, odpalał się od niego. „Rozpad Związku Radzieckiego oznaczał nagły koniec pax sovietica na Kaukazie. Wiązało się to nie tylko z zakwestionowaniem dotychczasowego porządku politycznego, ale i z rewolucyjnymi zmianami dotyczącymi tożsamości mieszkańców regionu" (Falkowski, 2010, s. 42). Zawalenie się sowieckiego świata pociągnęło za sobą szereg problemów tożsamościowych kaukaskich społeczności, zachwiało poczuciem jedności i przynależności do jednego państwa, jakim jawił się Związek Socjalistycznych Republik Radzieckich. Siedemdziesiąt lat sowietyzacji i budowanie homo soveticus nagle musiano zastąpić powrotem do korzeni, do ponownej identyfikacji z własnym tejpem (klanem) czy grupą etniczną. Polityka ZSRR wobec zamieszkujących ten teren narodów prowadzona była na sprzecznych ze sobą zasadach. Kierowała się marksistowską teorią rozwoju społecznego, która oparta była na teorii ewolucji. Teoria ta dawała nie tylko szansę każdej grupie społecznej (etnicznej) na rozwój, ale także nadzieję na to, że osiągnie ona kiedyś status narodu, co da jej możliwość stworzenia osobnego bytu państwowego. „Odpowiadało to podziałowi administracyjnemu imperium - w jego ramach tym grupom, którym nadano status narodów lub narodowości, przysługiwała, formalnie rzecz biorąc, autonomia polityczna, własne państwo w postaci tzw. republik związkowych (dla narodów) i republik autonomicznych (dla narodowości)” (por.: 
Ząbek, 2010, s. 25-26). Kiedy więc rozpadł się Związek Radziecki a Borys Jelcyn ogłosił, by wszystkie republiki brały dla siebie tyle wolności, ile uda im się udźwignąć, na Kaukazie zawrzało. Przy tak wielkim zróżnicowaniu etnicznym, z jakim mamy do czynienia w tym rejonie świata, nie trudno było o animozje i konflikty, tym bardziej iż były one podżegane przez Kreml. Koniec status quo, jakie dawał Związek Radziecki, spowodowało wzmożone zainteresowanie Kaukazem innych mocarstw. „Kaukaz wraz z Azją Centralną - przede wszystkim ze względu na tamtejsze zasoby surowcowe i szlaki transportowe - jest od rozpadu ZSRR obiektem Nowej Wielkiej Gry. Jej najważniejszymi uczestnikami są Stany Zjednoczone, Chiny, Turcja, Iran i Unia Europejska, których celem jest osłabienie wpływów rosyjskich w obu regionach, oraz Rosja dążąca do zachowania obszaru postsowieckiego pod swoją kontrolą" (Falkowski, 2010, s. 43). W interesie Rosji było więc zdestabilizować Kaukaz a pomocną i niezwykle skuteczną metodą okazała się być niezawodna, stosowana przez Moskwę od zawsze na szeroką skalę metoda divide et impera, która przy konfliktach etnicznych sprawdza się doskonale. „Twórcą podziału Kaukazu był Stalin, który sam był Kaukazczykiem i wiedział, jak skłócić górali, aby łatwiej nimi rządzić”" (Górecki, 2013, s. 49).

Dziś na tym terenie mamy do czynienia z pięcioma zamrożonymi konfliktami: Górski Karabach (pomiędzy Armenią a Azerbejdżanem), Osetia Południowa (pomiędzy Gruzją i Osetią a de facto Rosją), Czeczenia (między Czeczenią a Rosją), konflikt ingusko-osetyjski (por. Falkowski, 2010, s. 47-62) oraz będący treścią niniejszej pracy konflikt gruzińsko-abchaski (de facto gruzińsko-abchasko-rosyjski). Wojna pomiędzy Gruzją a Abchazją wybuchła 14 sierpnia 1992 r., kiedy to Tbilisi wprowadziło wojska do zbuntowanej prowincji. Preteksty były dwa. Po pierwsze - ochrona kolei, łączącej Gruzję i Armenię z Rosją i Europą (por.: Górecki, 2013, s. 21), a po drugie - pogoń za ukrywającymi się w obwodzie galskim (na granicy z Megrelią) zwolennikami Zwiada Gamsachurdii, gorącego przeciwnika ówczesnej głowy państwa - Eduarda Szewardnadzego ${ }^{1}$ (por.: Bartuzi, 2006, s. 807). De facto oddziały gruzińskiej Gwardii Narodowej wkroczyły do Abchazji w celu zajęcia autonomii i odsunięcia od władzy miejscowych notabli. Wszystko to „działo się [jednak] w prawnej próżni. Abchazja była republiką autonomiczną - ale w składzie Gruzińskiej Socjalistycznej

${ }^{1}$ Gruzja była w stanie wojny domowej między obozami politycznymi Zwiada Gamsachurdii oraz Eduarda Szewardnadzego 
Republiki Radzieckiej, która już nie istniała. Status Abchazji w ramach niepodległej Gruzji wymagał negocjacji, uzgodnień, nowych umów, odpowiednich zapisów w nowych konstytucjach" (Górecki, 2013, s. 21). Abchazja uciekała się w swoich argumentach do 1921 r. (a konkretnie do konstytucji z 1925 r.) $)^{2}$, kiedy to bolszewicy, tuż po zajęciu Kaukazu Południowego, nadali jej status republiki związkowej, który szybko zlikwidowano. Zdaniem Abchazji prawdziwymi przyczynami likwidacji abchaskiej republiki związkowej były dążenia Józefa Stalina i Ławrentija Berii by podporządkować ten region Gruzji (więcej: Marczuk, 2010, s. 129). Proceder ten Abchazowie nazywają także prezentem Stalina dla swych rodaków. Walki trwały do 30 września 1993 r. i zakończyły się klęską Gruzinów. Abchazję wspierały nieoficjalnie wojska rosyjskie oraz bojownicy z Konfederacji Narodów Kaukazu. „Rosja wsparła Abchazję, aby osłabić Gruzję, która obok republik bałtyckich najgłośniej domagała się niepodległości, a po rozpadzie ZSRR natychmiast chciała integrować się z Zachodem" (Górecki, 2013, s. 39). Abchazji jako niepodległego państwa nie uznał żaden kraj, ale w procesie pokojowym uczestniczyła ona na prawach identycznych z niepodległą Gruzją. Konflikt gruzińsko-abchaski został umiędzynarodowiony dopiero w 2008 r., kiedy to, w wyniku tzw. wojny pięciodniowej pomiędzy Gruzją a Osetią Południową̧, wspomaganą przez Rosję, ta oficjalnie uznała obie prowincje za niepodległe (Falkowski, 2010, s. 54; Górecki, 2013, s. 157; Jastrzębski, 2014, s. 50).

W wyniku wojny (1992-1993) Abchazję musiało opuścić około 250 tys. Gruzinów, spośród których około 45-55 tys. zezwolono na powrót, ale tylko do jednego regionu Abchazji - galskiego, leżącego tuż za granicą na rzece Inguri (Marczak, 2010, s. 131).

${ }^{2}$ W 1921 roku nadano Abchazji status republiki związkowej, który szybko zlikwidowano. Abchazja podpisała traktat akcesyjny, który włączał ją w strukturę Gruzińskiej SRR. Umowa ta została formalnie potwierdzona w 1931 roku, wtedy też Abchazja została zdegradowana do autonomicznej republiki pod zwierzchnictwem Gruzji.

${ }^{3}$ Wojna wybuchła 7 sierpnia 2008 r., kiedy to sprowokowany na pograniczu gruzińsko-osetyjskim prezydent Saakaszwili zdecydował się na wprowadzenie wojsk do stolicy zbuntowanej prowincji, Cchinwali. Rosjanie tego samego dnia wkroczyli do Osetii Południowej oraz do Abchazji, w celu obrony swoich obywateli. Należy zauważyć, że 9 sierpnia Rosjanie wraz z Abchazami zajęli górne Kodori, mimo że Gruzini nie prowadzili w tym rejonie żadnych działań wojennych. W wyniku działań wojsk rosyjskich i abchaskich Gruzja utraciła Wąwóz Kodorski, co spowodowało napływ do Gruzji dodatkowych 100 tys. uchodźców wewnętrznych (Falkowski, 2010, s. 54). 
PrZYMUSOWI PRZESIEDLEŃCY. OŚRODKI POBYTOWE - OGÓLNA CHARAKTERYSTYKA GRUZIŃSCY UCHODŹCY Z ABCHAZJI MAJĄ OSOBLIWĄ SYTUACJĘ I SPECYFICZNY status. To obywatele Gruzji, którzy są uchodźcami w swoim własnym państwie. Zgodnie z konwencją genewską z 1951 r. uchodźca wewnętrzny (internally displaced person - IDP) to osoba, która musi opuścić swój dom na skutek uzasadnionej obawy przed prześladowaniem z powodu swojej rasy, religii, narodowości, przynależności do określonej grupy społecznej lub z powodu przekonań politycznych, nie przekraczając granic uznawanych za międzynarodowe [http://unhcr.w.interiowo. pl/uchodzca.htm. dostęp: 29.12.2015]. Uchodźcy wewnętrzni stanowią bardzo poważny problem migracyjny w Gruzji. Formalnie podlegają opiece Ministerstwa ds. Uchodźstwa i Zakwaterowania, posiadają status przymusowego przesiedleńca co daje im możliwość ubiegania się o stosowną pomoc. Państwo zobowiązało się zapewnić im godne warunki mieszkaniowe do czasu, kiedy nie zostanie im przywrócone prawo powrotu do swoich domów. Zobowiązało się także do poprawy zdrowia uchodźców, wdrażania programów pomocowych oraz remontu zajmowanych przez nich budynków. Z przeprowadzonych badań terenowych wynika, że programy pomocowe były wprowadzane w życie - zbudowano między innymi osiedle mieszkaniowe w Zugdidi, które oddano do użytku w 2013 r. W okresie rządów Michaela Saakaszwielgo w niektórych ośrodkach (były zakład porcelany w Zugdidi) przeprowadzono remont części wspólnych zamieszkałych budynków, tj. korytarzy i łazienek. Niemniej jednak w omawianym ośrodku ani klatka schodowa ani piwnica nie zostały objęte renowacją. Mieszkańcy nie otrzymali także dotacji na ewentualny remont pomieszczeń mieszkalnych.

Generalnie ośrodki pobytowe dla uchodźców znajdują się w budynkach użyteczności publicznej (szkoły, przedszkola), byłych hotelach robotniczych, zakładach pracy. Ośrodki te nie są ani ogrodzone, ani dozorowane. W pokojach brak ubikacji, łazienek, kuchni, bieżącej wody. Rodziny umieszczane są razem, w jednym pomieszczeniu, spełniającym funkcję mieszkania, niekiedy poprzedzielanego dyktą, meblościanką czy kotarą, które to pełnią funkcje ścianek działowych. Pokoje z reguły ogrzewane są piecem wolnostojącym typu koza. Drewno rąbane jest w pomieszczeniach zamieszkanych przez rodziny. Na korytarzach bardzo często brak szyb w oknach, w okresie zimowym zastępuje je brezent, dykta lub karton. W zugdidskim ośrodku dla uchodźców, w którym wcześniej mieściło się Technikum im. Szoni, brak bieżącej wody. Ośrodek nie posiada pryszniców, wyposażony jest 
tylko w toalety, znajdujące się w budynku obok. Doprowadzono tam zimną wodę. „Najgorzej jest zimą, z dziećmi. Moja czteroletnia córka załatwia potrzeby fizjologiczne do foliowych reklamówek. Nie znalazłam póki co innego rozwiązania. Nie wyobrażam sobie nocą chodzić z nią do budynku obok" - twierdzi jedna z rozmówczyń. W tym czasowym miejscu pobytu mieszkańcy samodzielnie doprowadzili prąd. Kable wiszą prowizorycznie poprzyczepiane do dziur po oknach, sufitu, drzwi lub przypominających (czasem pełniących funkcję) anteny konstrukcji zbudowanych $\mathrm{z}$ desek i puszek. W byłym zakładzie porcelany w Zugdidi na każde piętro przypadają dwa prysznice z zimną wodą i jedna toaleta. Łazienki, korytarze i klatki schodowe pozbawione są szyb w oknach. Wokół budynków, w których mieszczą się obozy dla uchodźców panuje bałagan i nieporządek. „Nie ma żadnej inicjatywy, żeby to wszystko posprzątać. Każdy traktuje to jak nieswoje i nie poczuwa się w obowiązku by zebrać śmieci. W pokojach mamy czysto, ale wspólną częścią nikt się nie przejmuje. Latem w tych śmieciach biegają świnie, a teraz [zimą] wszystko leży przykryte warstwą błota" - stwierdza mieszkaniec. W mieszkaniach widać porządek i ład. Każdy mieszkaniec sprząta przy swoim obejściu. Korytarze pełnią funkcję suszarni. Na całej rozciągłości rozwieszone jest pranie. Na większości drzwi napisane jest imię i nazwisko mieszkańca oraz numer telefonu. Kłódki pełnią rolę zamków w drzwiach. Przy jednym z mieszkań waruje pies, którego łańcuch przymocowany jest do podłogi korytarza. Niektóre pokoje urządzone są lepiej, posiadają telewizory, lodówki, mikrofalówki (w byłej fabryce porcelany w Zugdidi niektóre mają krany z bieżącą wodą), inne gorzej - samo łóżko, piecyk, stół, krzesło. W niektórych mieszkaniach w okresie jesienno-zimowym funkcje lodówki pełni okno. Widać zasadniczą różnicę w mieszkaniach zamieszkiwanych przez rodziny a tych, w których mieszkają sami mężczyźni. W mieszkaniach samotnych mężczyzn zwykle panuje nieporządek, skromniejsze jest także wyposażenie. Tam, gdzie mieszkają kobiety widać próby zaprowadzenia porządku. Zdarzają się pomalowane kolorową farbą ściany pomieszczeń. W większości jednak farba łuszczy się i odchodzi od ścian.

Warunki mieszkaniowe w ośrodkach dalekie są od norm i bardzo prowizoryczne. Brak wody, prąd doprowadzany na własną rękę, brak szyb w oknach, brak ogrzewania, brak toalet i pryszniców nie pozwala na normalne funkcjonowanie mieszkańców ośrodków. Zwrócić należy szczególną uwagę na fakt, iż sytuacja nie zmienia się (w znakomitej większości) od 1993 roku, czyli od ponad dwudziestu lat. Wewnętrz- 
ni uchodźcy mają ograniczone możliwości odbudowy swojego życia, funkcjonują w zawieszeniu. „Moje życie jest zupełnie bez sensu. Nie chce mi się już. Mam wrażenie, że żyję tylko po to, by wydawać pieniądze. Tego nie można nazwać życiem. To po prostu istnienie" - konstatuje jedna z mieszkanek obozu. Na czterdzieści cztery przeprowadzone rozmowy czterdzieści osób skarży się na warunki mieszkaniowe. Cztery z nich to mieszkańcy nowopowstałego osiedla, rzeczywiście spełniającego warunki zarówno sanitarne, jak i metrażowe.

Skąpa pomoc finansowa państwa powoduje, że wewnętrzni uchodźcy pozostawieni są sami sobie, ze świadomością braku perspektyw na polepszenie sytuacji. Ze względu na teorię, iż uchodźstwo wewnętrzne jest zjawiskiem przejściowym, nikt nie stara się uregulować tej kwestii, pozostawiając ją w zawieszeniu. Dziś uchodźcy są zakładnikami wielkiej polityki między nieuznawaną na arenie międzynarodowej Abchazją ${ }^{4}$ oraz Gruzją. Z jednej strony niestabilna sytuacja ekonomiczna Tbilisi nie pozwala na normalizację warunków życia, a z drugiej ich los kłóci się z interesem politycznym zarówno Gruzji, jak i Abchazji. Istnieje ryzyko, że kiedy państwo zapewni im stabilność i w miarę normalny pobyt - sami nie będą chcieli wrócić do swoich domów, albo Abchazja może zakwestionować ich powrót. Abchazji z kolei nie jest na rękę przyjęcie abchaskich Gruzinów z powrotem z obawy, że znów staliby się mniejszością.

Istnieje jeszcze jeden, poza socjalnym, problem z wewnętrznymi uchodźcami. Jest nim znikoma akceptacja przez społeczeństwo gruzińskie. Abchaski uchodźca nie mówi w innym języku, nie różni się wyglądem, nie wyznaje innej religii, nie wychowywał się w innym kodzie kulturowym. Jest taki sam. Odróżnia go tylko to, że stracił wszystko, co miał. Status uchodźcy czyni go wykluczonym, gorszym, zepchniętym na margines społeczny. Jest więc swoim „Obcym”. Każda z ankietowanych osób czuje się nie u siebie, a akceptacja, czy nawet asymilacja, zależy od poziomu wykształcenia i wykonywanej pracy. Niemniej jednak, ośrodki budzą wrażenie wyobcowania i potęgują poczucie życia w enklawach. Interesującym faktem jest także to, że nowe pokolenia, które dorastały (a nawet rodziły się) już poza Abchazją, nazywają siebie „uchodźcami”.

${ }^{4}$ Abchazję jako niepodległe państwo uznała Rosja, Nikaragua, Wenezuela, Nauru, Vanuatu i Tuvalu. 


\section{BIBLIOGRAFIA}

Bartuzi W. (2006), Gruziński kocioł miedzy Abchazją, Osetia Południowa a Adżaria 1991-2006, [w:] Konflikty kolonialne i postkolonialne w Afryce i Azji 1869-2006, red. Piotra Ostaszewskiego, Warszawa.

Falkowski M. (2010), Najważniejsze problemy i konflikty wspótczesnego Kaukazu, [w:] Dylematy kaukaskie. Problemy narodowościowe i migracyjne, red. M. Ząbek, P. Prześlakiewicz, I. Kaliszewska, Warszawa.

Gralewski M. (2015), Kaukaz. Wspomnienia z dwunastoletniej niewoli, oprac. Przemysław Adamczewski, wyd. Zysk i S-ka, Poznań.

Górecki W. (2013), Abchazja, Wołowiec.

Górecki W. (2010), Planeta Kaukaz, Wołowiec.

Jagielski W. (2010), Dobre miejsce do umierania, Warszawa.

Jastrzębski M. (2014), Klątwa gruzińskiego tortu, Gliwice.

Kagarlicki B. (2012), Imperium peryferii. Rosja i system światowy, tłum. Ł. Leonkiewicz, B. Szulęcka, Warszawa.

Marczuk J. (2010), Narracje zniewolone. Gruzińsko-abchaski i gruzińsko-osetyjski dialog o tożsamości, wojnie oraz niepodległości, [w:] Dylematy kaukaskie. Problemy narodowościowe i migracyjne, red. M. Ząbek, P. Prześlakiewicz, I. Kaliszewska, Warszawa.

Unhcr.w.interiowo.pl/uchodzca.htm [dostęp: 29.12.2015].

Ząbek M. (2010), Wstęp. Problemy tożsamościowe regionu Kaukazu, [w:] Dylematy kaukaskie. Problemy narodowościowe i migracyjne, red. M. Ząbek, P. Prześlakiewicz, I. Kaliszewska, Warszawa.

\section{SUMMARY}

After the collapse of the Soviet Union, Georgia participated in the armed conflicts over South Ossetia (1991-1992 and 2008) and Abkhazia (1992-1993). As a consequence, Georgia had to accept forced displaced persons. The following thesis focuses on the Abkhazian conflict, its causes and effects. The thesis is based on the analysis of the specific situation of IDPs which has gone on since 1993. The thesis describes the living conditions and prospects of the group of Abkhazian Georgians who were displaced within the territory of their own country and became internally displaced persons. 
Nota O AUTORZE

Stanisława Budzisz-Cysewska [stasiabudzisz@o2.pl] - jestem absolwentką filologii polskiej oraz rosyjskiej Uniwersytetu Gdańskiego, aktualnie słuchaczką Filologicznego Studium Doktoranckiego Uniwersytetu Gdańskiego. Zajmuję się problematyką pamięci i neokolonializmu na terenach postsowieckich ze szczególnym uwzględnieniem Kaukazu. Publikowałam na łamach „Blizy. Kwartalnika artystycznego”, „Fragile. Pisma kulturalnego” oraz wielu portali internetowych. 